
RESEARCH AND DEVELOPMENT

\author{
http://journal.unnes.ac.id/sju/index.php/higeia
}

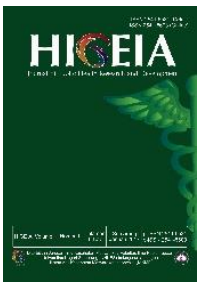

\title{
KINERJA PETUGAS SURVEILANS KESEHATAN DALAM UPAYA PENANGGULANGAN DEMAM BERDARAH DENGUE
}

\author{
Nurina Salsabila ${ }^{\bowtie}$, Bambang Budi Raharjo \\ Administrasi Kebijakan Kesehatan, Jurusan Ilmu Kesehatan Masyarakat, \\ Fakultas Ilmu Keolahragaan, Universitas Negeri Semarang
}

\section{Info Artikel}

Sejarah Artikel:

Diterima Februari 2018

Disetujui Maret 2018

Dipublikasikan April

2018

\section{Keywords:}

Performance, Gasurkes,

DHF Effort Prevention

\begin{abstract}
Abstrak
Pemerintah Kota Semarang melakukan upaya pengendalian kasus DBD dengan pembentukan Petugas Surveilans Kesehatan (Gasurkes) DBD sesuai Perda Kota Semarang Nomor 5 Tahun 2010. Kelurahan Meteseh dan Kelurahan Tembalang merupakan dua kelurahan yang menyumbang IR tertinggi. IR Kelurahan Meteseh tahun 2015 sebanyak 236,24/100.000 dan tahun 2016 sebanyak 241,96/100.000. IR Kelurahan Tembalang tahun 2015 sebanyak 246,22/100.000 dan tahun 2016 sebanyak 504,39/100.000. Tujuan penelitian untuk menganalisis kinerja Gasurkes dalam upaya penanggulangan DBD di kelurahan endemis. Jenis penelitian merupakan penelitian kualitatif dengan rancangan deskriptif diperoleh dengan wawancara mendalam kepada 4 informan utama dan 7 informan triangulasi ditentukan dengan teknik purposive sampling. Hasil menunjukkan pengetahuan Gasurkes kurang baik, terdapat persepsi baik, kurangnya motivasi, belum diberlakukannya imbalan, dukungan lingkungan sosial ekonomi politik yang belum optimal, proses kepemimpinan yang belum optimal, beban kerja yang belum merata, tenaga yang belum mencukupi dan sarana yang sudah mencukupi. Simpulan penelitian menunjukkan bahwa kinerja Gasurkes dalam upaya penanggulangan DBD di kelurahan endemis belum optimal.
\end{abstract}

\begin{abstract}
Semarang government made efforts to control DHF cases with the formation of health surveillance officers (Gasurkes) according to semarang city local regulation number 5 of 2010. Meteseh and tembalang urban village contributed the highest IR. The IR of Meteseh urban village in 2015 were 236,24/100.000 and 241,96/100.000 in 2016. The IR of Tembalang Village in 2015 were 246,22/100.000 and 504,39/100.000 in 2016. The purpose of this research was to analyze the performance of in effort to prevent DHF in endemic village. The type of this research was qualitative research with descriptive design obtained by in-depth interview to 4 main informant and 7 triangulation informant were determined by purposive sampling technique. The result showed that the knowledge of Gasurkes was not good, there was good perception, lack of motivation, unenacted reward, socio-economic environment support not optimal, leadership process had not optimal, uneven workload, insufficient staff and sufficient facilities. The conclusions of the research showed that the performance of Gasurkes in the effort of DHF prevention in endemic village had not optimal.
\end{abstract}

(C) 2018 Universitas Negeri Semarang

Alamat korespondensi:

Gedung F5 Lantai 2 FIK Unnes

p ISSN 1475-362846

Kampus Sekaran, Gunungpati, Semarang, 50229

e ISSN 1475-222656

E-mail: nurinasalsabila@gmail.com 


\section{PENDAHULUAN}

Penyakit DBD merupakan permasalahan serius di Provinsi Jawa Tengah. Berdasarkan data dari Dinas Kesehatan Kota Semarang bahwa Angka Bebas Jentik (ABJ) yang meningkat dapat menurunkan kasus DBD. Hal tersebut jelas berhubungan signifikan karena DBD hanya dapat ditularkan melalui nyamuk, sehingga $A B J$ merupakan salah satu indikator yang valid untuk menggambarkan tren $\mathrm{DBD}$, dengan demikian validitas $A B J$ dapat memprediksi perkembangan kasus DBD. Incidence Rate (IR) DBD di Provinsi Jawa Tengah tahun 2015 sebesar 47,9 per 100.000 penduduk, mengalami peningkatan dibandingkan tahun 2014 yaitu 36,2 per 100.000 penduduk. Hal ini menunjukkan bahwa IR DBD di Jawa Tengah lebih rendah dari target nasional ( $<51 / 100.000$ penduduk), namun lebih tinggi jika dibandingkan dengan target Rencana Pembangunan Jangka Menengah Daerah (RPJMD) yaitu <20/100.000 penduduk (Dinkes Kota Semarang, 2015).

Pada tahun 2013 Kota Semarang merupakan daerah dengan IR DBD yang tinggi yaitu sebesar 134,09 per 100.000 penduduk, Angka Kematian (CFCR) sebesar 1,14\%. Kemudian pada tahun 2014 IR DBD turun menjadi 92,43 per 100.000 penduduk, dan CFR tetap pada $1,14 \%$. Pada tahun 2013, IR tertinggi terdapat di Kecamatan Tembalang sebesar 218,20 per 100.000 penduduk, dengan (CFR) 0,53\%. Angka Bebas Jentik (ABJ) sebesar $77,2 \%$. Kemudian pada tahun 2014 IR menurun menjadi 166,89 per 100.000 penduduk, sedangkan CFR meningkat menjadi $1,02 \%$. ABJ di tahun tersebut sebesar $82,4 \%$. Target Angka Bebas Jentik di Kecamatan Tembalang sendiri yaitu 90\% (Dinkes Kota Semarang, 2015).

Salah satu upaya Pemerintah Kota Semarang tersebut adalah dengan membentuk Petugas Surveilans Kesehatan (Gasurkes) DBD sesuai Perda Kota Semarang Nomor 5 Tahun 2010. Program tersebut bertujuan untuk menekan jumlah kasus DBD di Kota Semarang. Peran Gasurkes adalah sebagai fasilitator dalam pemecahan masalah DBD dengan cara memberikan pemeriksaan jentik serta memberikan penyuluhan tentang DBD. Gasurkes mulai ditugaskan sejak tanggal 2 Januari 2015 di seluruh wilayah kelurahan kota Semarang. Tetapi faktanya setelah di bentuk Gasurkes tren IR dan CFR DBD juga meningkat. Pada tahun 2015 IR DBD Kota Semarang meningkat mencapai 98,61 per 100.000 penduduk, dan CFR meningkat menjadi $1,21 \%$. Pada tahun 2016 IR turun menjadi 31,83 per 100.000 penduduk, berbeda dengan CFR yang mengalami peningkatan hingga 5,13\% (Dinkes Kota Semarang, 2015).

Demikian pula di lingkup Kecamatan Tembalang, pada tahun 2015 IR meningkat kembali menjadi 194,04 per 100.000 penduduk dan tidak ditemukan CFR. Pada tahun tersebut ditemukan pula ABJ sebesar 79,03\%. Tahun 2016 di Kecamatan Tembalang IR DBD mengalami peningkatan mencapai 217 per 100.000 penduduk. Begitu pula CFR turut meningkat mencapai 1,53\%. Dari bulan April sampai dengan bulan Desember ditemukan ABJ sebesar 45,83\%. Namun demikian dengan penempatan Gasurkes di Kecamatan Tembalang tidak turut diimbangi dengan adanya penurunan jumlah kasus DBD di tahun 2015 dan 2016. Selama tahun 2015 sampai tahun 2017 Kelurahan Meteseh dan Tembalang merupakan dua kelurahan yang menyumbang IR tertinggi. Di kelurahan Meteseh IR pada tahun 2015 adalah 236,24 per 100.000 penduduk, CFR tidak ditemukan, dan ABJ sebesar 81,83\%. Kemudian pada tahun 2016 IR naik mencapai 241,96 per 100.000 penduduk, CFR naik mencapai 4,08\% dan ABJ bulan April hingga bulan Desember sebesar 44,25\%. Pada awal tahun 2017 ini IR DBD mengalami peningkatan menjadi 60,47 per 100.000 penduduk, dan CFR mencapai 8,33\%. Sedangkan IR di Kelurahan Tembalang pada tahun 2015 adalah 246,22 per 100.000 penduduk, tahun 2016 naik mencapai 504,39 per 100.000 penduduk. Tahun 2017 mengalami peningkatan mencapai 54,21 per 100.000 penduduk. Kelurahan Tembalang tidak menyumbang angka CFR. Upaya 
pemberantasan nyamuk penular sudah dilakukan melalui berbagai cara, akan tetapi hasilnya belum seperti yang diharapkan. Perilaku masyarakat mempunyai peranan penting terhadap penularan DBD, namun perilaku tersebut harus didukung oleh pengetahuan misalnya pengetahuan cara penularan, penanggulangan serta sikap dan tindakan yang benar sehingga dapat diterapkan dengan benar (Dinkes Kota Semarang, 2015).

Berdasarkan penelitian Armaya (2016) disebutkan bahwa Gasurkes memiliki tugas rangkap, yaitu pemeriksaan jentik rutin dan melakukan penyuluhan serta melakukan pendataan dan pendampingan ibu hamil. Sehingga dalam pelaksanaannya Gasurkes tidak maksimal dalam bekerja karena harus membagi waktu dengan pendampingan dan pendataan ibu hamil.

Handayani (2012) menyebutkan bahwa seberapa baik karyawan bekerja akan mempengaruhi produktivitas dan kinerja organisasional secara signifikan. Faktor-faktor yang mempengaruhi sumber daya manusia dalam menunjukkan kinerjanya berasal dari dalam diri maupun dari luar dirinya. Faktor yang berasal dari dalam diri yaitu pengetahuan, kompetensi yang sesuai dengan pekerjaannya, motivasi kerja, persepsi, kepribadian, sikap, dan perilaku. Sedangkan faktor yang berasal dari luar adalah kepemimpinan, imbalan, yang berperan dalam mempengaruhi kinerja pekerjanya. Selain itu juga dipengaruhi oleh sumber daya lainnya yaitu dana, bahan, sarana, dan teknologi yang ada di dalam suatu organisasi (Wibowo, 2011). Haryanti (2011) bahwa manajemen sumber daya manusia (ketersediaan tenaga) merupakan hal yang sangat penting dalam suatu organisasi.

Berdasarkan penelitian Rundungan (2015) menunjukkan bahwa motivasi, kemampuan kerja, pengalaman kerja dan sarana atau fasilitas berpengaruh terhadap pelayanan kesehatan gigi dan mulut. Sehingga diperlukan dukungan dan perhatian dari pemerintah untuk meningkatkan kinerja dari petugas kesehatan gigi dan mulut. Adanya ketentuan serta penilaian kerja yang memiliki indikator- indikator yang pasti, keterampilan dalam komunikasi, koordinasi antara Bikor dan Gasurkes, gaji, uang transportasi, supervisi, struktur dan desain kerja, persepsi Gasurkes dan motivasi yang dimiliki Gasurkes dapat mempengaruhi kinerja Gasurkes KIA (Armaya, 2016).

Berdasarkan hasil wawancara dengan pihak Koordinator Kecamatan Gasurkes DBD Kecamatan Tembalang, beberapa kasus ditemukan pada masyarakat yang menolak rumahnya dilakukan pemantauan jentik oleh Gasurkes, terutama pada perumahan elit. Gasurkes koordinasi dengan pihak kelurahan namun kelurahan tidak bisa mengupayakan untuk pemantauan jentik di wilayah tersebut.

Dalam pelaksanaannya upaya pengendalian DBD belum semua dilaksanakan sesuai Peraturan Daerah Kota Semarang Nomor 5 Tahun 2010 tentang Pengendalian Penyakit DBD masih terdapat beberapa kendala dalam pelaksanaan upaya pengendalian DBD diantaranya masih terdapat penolakan untuk dilakukan pemantauan jentik dan sanksi-sanksi yang terdapat didalam peraturan belum dilaksanakan (Rahmawati, 2016).

Berdasarkan latar belakang maka tujuan penelitian ini yaitu menganalisis Kinerja Petugas Surveilans Kesehatan (Gasurkes) dalam Upaya Penanggulangan Demam Berdarah Dengue (DBD).

\section{METODE}

Penelitian ini difokuskan pada kinerja petugas surveilans kesehatan Kelurahan Meteseh dan Kelurahan Tembalang Kota Semarang yang terdiri dari beberapa variabel, antara lain pengetahuan, persepsi, motivasi, kepemimpinan, beban kerja, kondisi sosial politik dan ekonomi, kecukupan sarana, kecukupan tenaga, dan imbalan.

Jenis dan rancangan penelitian menggunakan jenis penelitian deskriptif dengan pendekatan kualitatif. Metode penelitian deskriptif kualitatif dipilih agar hasil penelitian yang dilakukan dapat memberikan gambaran analisis kinerja petugas surveilans kesehatan 
program DBD secara objektif pada saat sekarang. Jenis penelitian deskriptif kualitatif ini menggunakan rancangan penelitian studi kasus. Penelitian ini dilakukan pada bulan Agustus 2017 di wilayah Kelurahan Meteseh dan Kelurahan Tembalang.

Sumber data yang digunakan dalam penelitian ini terdiri dari sumber data primer dan sumber data sekunder. Sumber data primer diperoleh dari lokasi penelitian dan data yang berasal dari informan yang berkaitan dengan kinerja Petugas Surveilans Kesehatan program DBD di Kelurahan Meteseh dan Kelurahan Tembalang Kecamatan Tembalang yang dilakukan dengan cara wawancara mendalam (Indepth Interview). Penentuan informan dalam penelitian ini menggunakan teknik purposive sampling. Informan dalam penelitian ini dibagi dua kategori yaitu informan utama dan informan triangulasi. Informan dalam penelitian ini berjumlah 11 orang yang terdiri 4 orang informan utama yaitu Gasurkes dari Kelurahan Meteseh dan Kelurahan Tembalang yang bertanggung jawab dan terjun langsung dalam upaya penanggulangan $\mathrm{DBD}$ dan 7 orang informan triangulasi yaitu pimpinan daerah terkait atau koordinator yang berwenang dalam upaya penanggulangan DBD di Kota Semarang. Sumber data sekunder penelitian ini diperoleh dari laporan, dokumen, maupun buku teks yang terdapat pada instansi maupun pada kepustakaan yang berhubungan dengan masalah yang dibahas. Data sekunder yang digunakan adalah data jumlah kasus DBD di wilayah kerja Kota Semarang pada tahun 2013 sampai tahun 2017.

Instrumen penelitian yang digunakan dalam penelitian ini adalah panduan wawancara. Panduan wawancara berisi pertanyaan yang digunakan sebagai panduan untuk mengumpulkan data dari subjek penelitian atau responden mengenai identitas responden dan variabel-variabel yang mempengaruhi kinerja petugas surveilans kesehatan program DBD. Selain peneliti sebagai instrumen utama, terdapat instrumen lain yang dapat mendukung proses berlangsungnya pengambilan data primer dari informan, antara lain panduan wawancara, catatan lapangan (fieldnotes), dan alat perekam suara.

Prosedur penelitian dalam penelitian ini adalah kegiatan menyusun rancangan awal penelitian antara lain mencari informasi awal melalui review dokumen-dokumen yang relevan seperti jurnal, berita, buku-buku, dan juga datadata dari instansi terkait yang dapat dipertanggungjawabkan. Setelah menyusun rancangan awal penelitian, selanjutnya memilih tempat penelitian yang dilanjutkan mengurus perizinan. Dalam memilih lapangan penelitian, peneliti tidak secara langsung terjun ke lapangan untuk observasi dan perizinan pada penelitian ini ditujukan kepada Kepala Kesbangpolinmas Kota Semarang dan Dinas Kesehatan Kota Semarang. Selain itu ada pula perizinan informal, yaitu perizinan kepada beberapa pejabat daerah di lokasi pengambilan data.

Teknik yang digunakan untuk memeriksa keabsahan data dalam penelitian ini dilakukan dengan menggunakan teknik triangulasi. Triangulasi adalah teknik pemeriksaan keabsahan data yang memanfaatkan sesuatu yang lain di luar data itu untuk keperluan pengecekan data atau sebagai pembanding terhadap data tersebut. Triangulasi yang digunakan dalam penelitian ini adalah triangulasi sumber. Triangulasi sumber dilakukan dengan cara mengecek data yang telah diperoleh melalui beberapa sumber. Informan berperan sebagai triangulasi adalah kasi kesos kelurahan Meteseh dan Kelurahan Tembalang, kasi kesos Kecamatan Tembalang, Pemegang Program P2P Puskesmas Rowosari, Koordinator Gasurkes DBD Dinas Kesehatan Kota Semarang, dan perwakilan masyarakat (PPJ) dari masing-masing kelurahan.

Kegiatan analisis data yang dilakukan dalam penelitian ini antara lain, 1) Reduksi data, Reduksi data dilakukan untuk menghilangkan/membuang data-data yang tidak diperlukan. Mereduksi data berati merangkum, memilih hal-hal yang pokok, dan memfokuskan pada hal-hal yang penting., 2) Penyajian data, Dalam penelitian kualitatif penyajian data bisa dilakukan dalam bentuk uraian singkat (narasi), bagan, tabel, grafik, dan 
sejenisnya dengan penyajian data, maka akan lebih mudah memahami apa yang terjadi karena data sudah terorganisir dan tersusun., 3) Penarikan kesimpulan, Data yang telah direduksi dan disajikan kemudian dilakukan penarikan kesimpulan berdasarkan pengamatan secara menyeluruh dari data-data yang sudah terkumpul pada tahap penelitian. Penarikan kesimpulan dalam bentuk penjelasan kalimatkalimat yang mudah dipahami.

\section{HASIL DAN PEMBAHASAN}

Pada tahun 2015 Kota Semarang memiliki Gasurkes DBD sebanyak 197 orang, di tahun 2016 Kota Semarang memiliki Gasurkes DBD sebanyak 227 orang dan di tahun 2017 Kota Semarang memiliki Gasurkes DBD sebanyak 215 orang. Penambahan jumlah gasukres dimaksudkan agar setiap wilayah di Kota Semarang dapat terjangkau oleh pelayanan Gasurkes sehingga kejadian DBD dapat ditekan secara perlahan. Di Kelurahan
Tembalang terdapat 1 orang Gasurkes yang bekerja mencakup 8 RW dan 35 RT. Gasurkes di Kelurahan Tembalang terhitung baru karena baru bekerja selama 1 bulan. Sedangkan di Kelurahan Meteseh terdapat 3 orang Gasurkes yang bekerja mencakup $30 \mathrm{RW}$ dan $186 \mathrm{RT}$. Terdapat 2 Gasurkes lama yang bekerja selama 3 tahun serta 1 Gasurkes baru yang baru bekerja selama 1 bulan.

Berdasarkan tabel 1 informan utama berjumlah 4 orang dengan jenis kelamin perempuan. Semua informan berada pada usia produktif 20 - 30 tahun. Dari segi latar belakang pendidikan semua informan berasal dari bidang kesehatan dengan 2 orang informan memiliki tingkat pendidikan S1 keperawatan dan 2 orang lainnya memiliki tingkat pendidikan S1 Kesehatan masyarakat. Informan utama merupakan Gasurkes DBD wilayah kerja Kelurahan Meteseh dan Kelurahan Tembalang.

Berdasarkan tabel 2, informan triangulasi dalam penelitian ini berjumlah 7 orang, 6 informan berjenis kelamin perempuan dan 1

Tabel 1 Karakteristik Informan Utama

\begin{tabular}{|c|c|c|c|c|}
\hline $\begin{array}{c}\text { Informan Utama } \\
\text { Ke- }\end{array}$ & Jenis Kelamin & $\begin{array}{c}\text { Usia } \\
\text { (tahun) }\end{array}$ & Pendidikan Terakhir & Jabatan \\
\hline Informan 1 & Perempuan & 27 & S1 Keperawatan & $\begin{array}{l}\text { Gasurkes DBD Kel. } \\
\text { Meteseh }\end{array}$ \\
\hline Informan 2 & Perempuan & 26 & S1 Keperawatan & $\begin{array}{l}\text { Gasurkes DBD Kel. } \\
\text { Meteseh }\end{array}$ \\
\hline Informan 3 & Perempuan & 22 & $\begin{array}{l}\text { S1 Kesehatan } \\
\text { Masyarakat }\end{array}$ & $\begin{array}{l}\text { Gasurkes DBD Kel. } \\
\text { Meteseh }\end{array}$ \\
\hline Informan 4 & Perempuan & 22 & $\begin{array}{l}\text { S1 Kesehatan } \\
\text { Masyarakat }\end{array}$ & $\begin{array}{l}\text { Gasurkes DBD Kel. } \\
\text { Tembalang }\end{array}$ \\
\hline
\end{tabular}

Tabel 2 Karakteristik Informan Triangulasi

\begin{tabular}{|c|c|c|c|c|}
\hline $\begin{array}{c}\text { Informan } \\
\text { Triangulasi Ke- }\end{array}$ & Jenis Kelamin & $\begin{array}{c}\text { Usia } \\
\text { (tahun) }\end{array}$ & $\begin{array}{c}\text { Pendidikan } \\
\text { Terakhir }\end{array}$ & Jabatan \\
\hline Triangulasi 1 & Perempuan & 49 & SLTA & PPJ Meteseh \\
\hline Triangulasi 2 & Perempuan & & SLTA & PPJ Tembalang \\
\hline Triangulasi 3 & Perempuan & 51 & SLTA & Kasi Kesos Kel. Meteseh \\
\hline Triangulasi 4 & Perempuan & 42 & S2 & Kasi Kesos Kel. Tembalang \\
\hline Triangulasi 5 & Perempuan & 56 & DIII & Kasi Kesos Kec. Tembalang \\
\hline Triangulasi 6 & Laki-laki & 34 & $\begin{array}{l}\text { S1 Kesehatan } \\
\text { Masyarakat }\end{array}$ & $\begin{array}{l}\text { Pemegang Program P2P } \\
\text { Puskesmas Rowosari }\end{array}$ \\
\hline Triangulasi 7 & Perempuan & 25 & $\begin{array}{l}\text { S1 Kesehatan } \\
\text { Masyarakat }\end{array}$ & $\begin{array}{l}\text { Koordinator Kota Gasurkes } \\
\text { DBD }\end{array}$ \\
\hline
\end{tabular}


orang berjenis kelamin laki-laki. Semua informan triangulasi berada pada usia produktif dengan usia 25 tahun hingga 56 tahun. Pendidikan terakhir informan sebanyak 3 orang adalah SLTA, 1 orang DIII, 2 orang S1 dan 1 orang S2. Dari 7 orang informan triangulasi adalah 2 orang PPJ, 2 orang Kasi Kesos Kelurahan, 1 orang Kasi Kesos Kecamatan, 1 orang Pemegang Program P2P Puskesmas Rowosari dan 1 orang Koordinator Kota Gasurkes DBD Kota Semarang.

Petugas Surveilans Kesehatan (Gasurkes) merupakan manifestasi dari Petugas Pemantau Jentik (PPJ) yang disebutkan didalam Perda Nomor 5 Tahun 2010 Bab I Ketentuan Umum Pasal 1 Point 30. Dalam Perda Nomor 5 Tahun 2010 disebutkan bahwa PPJ adalah orang yang ditunjuk dan diberi tugas untuk melakukan Pemeriksaan Jentik Rutin (PJR), mengumpulkan dan melaporkan data PJR, penyuluhan dan menggerakkan masyarakat. Tugas dari PPJ tersebut sama dengan Tupoksi yang diemban oleh Gasurkes yang bekerja sebagai Petugas Surveilans Kesehatan.

Mekanisme pelaksanaan pemeriksaan jentik di rumah warga, sekolah, pondok pesantren, tempat ibadah, kantor, dan bangunan lain yang dilakukan oleh Gasurkes DBD sudah sesuai dengan prosedur dan target yaitu 1 minggu 100 rumah apabila 1 bulan terdapat 4 minggu maka 400 rumah. Kegiatan PSN tersebut dilakukan secara terus-menerus dan berkesinambungan dengan cara membasmi telur, jentik dan nyamuk di semua tempat yang memungkinkan menjadi tempat perkembangbiakannya. Wajib dilakukan pengulangan pada bangunan positif jentik minimal 1 minggu sekali. Pengulangan pada rumah positif dengan edukasi juga sudah dilakukan oleh Gasurkes DBD. Apabila ditemukan positif jentik hingga 3 kali akan diberikan teguran tertulis (surat) oleh ketua RT atau ketua RW atau Lurah. Teguran tertulis juga diikuti dengan pemasangan tanda khusus (stiker) warna hijau, kuning, lalu merah. Setelah adanya surat teguran dan masih ditemukan positif jentik hingga positif 5,berdasarkan Perda No.5 tahun 2010 akan dikenakan sanksi yaitu berupa denda sebesar Rp.50.000.000 (lima puluh juta rupiah) atau tindak pidana selama 6 bulan yang dilakukan oleh Satpol PP yang bertugas sebagai penegak hukum bersama tim dari DKK dan tata pemerintahan lintas sektoral lainnya.

Target penyuluhan kesehatan adalah 12 kali dalam 1 bulan sesuai dengan target Kerja Gasurkes dalam Perda No. 5 Tahun 2010. Penyuluhan dilakukan pada masyarakat, sekolah dan lintas sektoral. Target penyuluhan kesehatan di masyarakat sebanyak 8 kali, penyuluhan di sekolah 4 kali dan atau pada lintas sektor 1 kali contohnya di wilayah tempat mahasiswa KKN.

Pengumpulan data dan kontak person untuk komunikasi dan advokasi pemangku wilayah sudah dilakukan oleh Gasurkes yang mana batas pengumpulan di awal bulan tahun 2015. Pemangku wilayah terdiri dari Camat, Lurah, Kepala Puskesmas, Pemegang program P2P Puskesmas, Ketua RT, Ketua RW, Ketua PKK RT, Ketua PKK RW, tokoh masyarakat, dan kader kesehatan.

Sistem pelaporan dan koordinasi sesuai dengan target yang tercantum dalam Perda No.5 Tahun 2010. Laporan pemantauan jentik dan penyuluhan di laporkan kepada DKK melalui korcam setiap 1 bulan sekali, laporan ke kelurahan 1 minggu sekali dalam bentuk print out. Koordinasi kelurahan dilakukan setiap hari, karena Gasurkes diwajibkan mengisi presensi yang ada di kelurahan masing-masing. Koordinasi dengan puskesmas dilakukan selama 1-2 kali dalam seminggu di wilayah kerja masing-masing puskesmas yang dihadiri oleh koordinator kecamatan.

PSN rutin merupakan kegiatan DBD yang wajib diikuti oleh Gasurkes DBD. PSN rutin ini dilakukan setiap 1 minggu sekali pada hari Jumat yang biasa disebut dengan jumat bersih. Kegiatan ini diikuti masing-masing Gasurkes, kader, kasi kesos kelurahan, kasi kesos atau perwakilan kecamatan dan puskesmas. PSN rutin dilakukan pada seluruh wilayah kerja masing-masing secara bergantian sesuai dengan jadwal yang telah dikoordinasikan sebelumnya. 
Berdasarkan hasil penelitian, kinerja Gasurkes DBD sesuai dengan target yang tercantum dalam Perda No 5 tahun 2010. Target yang harus dicapai, antara lain: (1) Melakukan pemeriksaan jentik di rumah warga, yang positif jentik diulang, (2) Pemeriksaan jentik di sekolah, pondok pesantren, tempat ibadah, kantor, (3) Melakukan penyuluhan DBD, (4) Mengumpulkan data dan kontak person untuk komunikasi dan advokasi, (5) Koordinasi dan melaporkan kegiatan pengendalian DBD, (6) Mengikuti kegiatan DBD tingkat kelurahan, kecamatan, dan kota. Kemampuan kerja Gasurkes yang baik di tandai dengan indikator keterampilan kerja yang sangat baik. Indikator ini menunjukkan adanya keahlian dan kemampuan pegawai mengerjakan semua tugasnya.

Gasurkes adalah sebagai fasilitator kesehatan yang harus bisa menyelesaikan masalah, menganalisis, mendorong masyarakat untuk menjadi mandiri. Pada tahun 2015 DBD merupakan masalah terbesar yang ada di Kota Semarang akhirnya dibentuklah Petugas Surveilans Kesehatan (Gasurkes) yang bertugas melakukan pemeriksaan jentik dan penyuluhan kesehatan. Indikator pencapaian target dari tujuan dibentuknya Gasurkes adalah ABJ yang sudah mencapai $95 \%$ serta sudah tidak lagi angka kejadian DBD. Berdasarkan hasil penelitian Gasurkes memiliki pengetahuan yang kurang. Terbukti dengan hasil wawancara tentang penyebab $\mathrm{DBD}$, cara penularan, tanda gejala awal dan lanjut penderita penyakit DBD, pertolongan pertama yang dilakukan bila penderita dengan tanda gejala lanjut, ciri-ciri jentik nyamuk Aedes aegypti, tempat perkembangbiakan nyamuk Aedes aegypti, dan cara pencegahan. Rata-rata Gasurkes kurang tepat menjawab pertanyaan mengenai tanda gejala awal dan lanjut dan pertolongan yang dilakukan bila penderita dengan tanda gejala awal dan lanjut. Tetapi menurut informan triangulasi pengetahuan yang dimiliki Gasurkes baik karena lolos tahap seleksi penerimaan Gasurkes. Menurut Gibson (1996) dalam Handayani (2012) menyatakan kemampuan dan keterampilan dapat mempengaruhi kinerja seseorang. Menurut Sutanti (2003) dalam Handayani (2012) menyatakan ada hubungan antara pengetahuan dengan kinerja bidan desa dalam pelayanan ibu hamil dan neonatal di Kabupaten Lampung Barat. Akan tetapi tidak sejalan dengan penelitian Mardiono (2016) yang menyatakan bahwa tidak ada pengaruh pengetahuan terhadap kinerja perawat dalam pelayanan keperawatan di Rumah Sakit Muhammadiyah. Masalah pelatihan adalah salah satu bagian yang terpenting dalam pengembangan sumber daya manusia, sehingga dalam menunjang kinerja karyawan yang bekerja maka pihak Puskesmas Ngesrep melakukan pelatihan untuk para karyawannya (Tryanto, 2017).

Persepsi dapat mempengaruhi perilaku seseorang. Hal ini mengandung makna bahwa melalui persepsi terhadap suatu objek (baik, buruk, positif, negatif, benar dan salah) maka timbul respon pada seseorang sehingga menjadi dasar dalam menentukan sikap (positif atau negatif). Hal ini akan berpengaruh pada motivasi seseorang sesuai persepsi yang telah dimiliki. Artinya ketika obyek yang dipersepsi sesuai dengan kebutuhan atau keinginannya maka akan menimbulkan motivasi untuk bertindak. Jika Gasurkes telah memiliki persepsi yang baik mengenai tugas dan tanggung jawabnya dalam menanggulangi DBD dapat menekan jumlah kasus DBD, maka Gasurkes merasa perlu untuk bertindak sesuai dengan konsep dibentuknya Gasurkes.

Menurut hasil penelitian, terdapat persamaan persepsi baik antara informan utama dan informan triangulasi terhadap kemampuan atau kecakapan yang dibutuhkan Gasurkes, latar belakang pendidikan mempengaruhi kinerja Gasurkes, dan keefektifan kinerja Gasurkes dalam menekankan kasus DBD. Secara kualitas keefektifan peranan Gasurkes dalam menanggulangi DBD dapat dilihat pada kerja sama antara masyarakat dengan pihak kecamatan, kelurahan serta kader akan tetapi dalam kuantitas, angka kejadian DBD masih tinggi di Kelurahan Tembalang dan Kelurahan Meteseh. Berbeda dengan penelitian Rahmah (2015) yang menyatakan bahwa pendidikan 
tidak berhubungan secara signifikan terhadap kinerja petugas vaksinasi di Kabupaten Aceh timur.

Motivasi merupakan faktor dalam kompetensi yang dapat berubah dengan memberikan dorongan, apresiasi terhadap pekerjaan bawahan, memberikan pengakuan dan perhatian individual dari atasan dapat berpengaruh positif terhadap motivasi seorang bawahan. Faktor higiene (ekstrinsik) memotivasi seseorang mencapai kepuasan terdiri dari hubungan antar manusia, imbalan, kondisi lingkungan, dan sebagainya sedangkan faktor intrinsik yaitu achievement, pengakuan, kemajuan tingkat kehidupan, dan sebagainya. Pelaksanaan penanggulangan DBD di Kelurahan Tembalang dan Kelurahan Meteseh didukung oleh semua pihak antara lain Kelurahan, Kecamatan, Puskesmas dan Dinas Kesehatan. Puskesmas dan Dinas Kesehatan rutin memberikan motivasi seperti dukungan secara langsung. Tetapi berdasarkan wawancara salah satu informan menyampaikan bahwa kurang adanya dukungan dari kasi kesos Kelurahan. Hal tersebut menjadi kendala tersendiri bagi Gasurkes Kelurahan Tembalang. Berdasarkan penelitian Husaini (2016) menyatakan bahwa motivasi kerja yang baik berpengaruh positif terhadap kepuasan kerja dan kinerja karyawan. Menurut penelitian Handayani (2012) menunjukkan bahwa ada hubungan antara motivasi dengan kinerja petugas MTBS yang sejalan dengan teori Gibson (1996), Robert L Mathis \& John H Jackson (2006) dan teori Amstrong \& Baron (1998) yang ketiganya menyatakan bahwa motivasi mempengaruhi kinerja seseorang. Berdasarkan hasil penelitian Salam (2013) tenaga kesehatan yang diberi dukungan yang tinggi dan terjadi komunikasi dua arah antara pimpinan dan tenaga kesehatan dalam pemecahan masalah maka kinerja tenaga kesehatan akan lebih baik. Dukungan dari orang-orang terdekat individu dapat mempengaruhi kinerja individu menjadi lebih baik lagi. Motivasi positif bagi individu akan meningkat apabila memperoleh dukungan dari orang-orang terdekat (Herdywati, 2017)
Imbalan dipandang sebagai salah satu tantangan yang harus dihadapi oleh suatu organisasi. Sistem imbalan yang baik adalah sistem yang mampu menjamin kepuasan pada anggota organisasi yang pada gilirannya memungkinkan organisasi memperoleh, memelihara, dan mempekerjakan sejumlah orang dengan berbagai sikap dan perilaku positif bekerja dengan produktif bagi kepentingan organisasi. Berdasarkan Perda yang mengatur, sanksi diberlakukan apabila tidak dapat melaksanakan tugas, tidak memenuhi target, memanipulasi data serta mencemarkan nama baik Dinas Kesehatan Kota Semarang maka akan diberhentikan dari Petugas Surveilans Kesehatan (Gasurkes). Apabila diberhentikan atau mengundurkan diri dari Gasurkes dikenakan mengganti biaya sebesar 5 kali honor yang pernah diterima. Berdasarkan wawancara imbalan yang diterima Gasurkes tidak sepadan dengan tugas yang mereka kerjakan. Punishment yang diberlakukan bagi mereka yang terbukti memanipulasi data dan pengunduran diri tanpa alasan yaitu pemberhentian kerja dengan denda sebesar 5 juta rupiah sesuai dengan Perda No.5 Tahun 2010 Bab II pasal 2 bahwa akan memberikan sanksi terhadap pelanggaran Peraturan Daerah tentang Pengendalian DBD. Tidak ada reward atau kompensasi yang diberlakukan walaupun tugas yang dikerjakan melebihi target kerja. Hal ini tidak sesuai dengan Perda No. 5 Tahun 2010 Bab II pasal 2 menyebutkan bahwa memberikan penghargaan kepada pihak-pihak yang berjasa terhadap upaya pengendalian penyakit DBD. Berdasarkan hasil penelitian Mandagi (2015) dengan adanya sistem penghargaan yang baik membuat perawat termotivasi dalam melakukan pekerjaannya serta bisa meningkatkan kinerja perawat yang diharapkan bisa membuat puas pasien akibat pelayanan yang diberikan. Pemberian reward kepada karyawan memberikan nilai plus bagi karyawan dalam meningkatkan kualitas kerja di perusahaan. Dimana dalam memberikan reward harus bersifat objektif dan sesuai dengan kinerja dari karyawan tersebut dan kompensasi mengandung adanya hubungan yang sifatnya 
profesional dimana salah satu tujuan utama karyawan bekerja adalah mendapatkan imbalan untuk mencukupi berbagai kebutuhan, sementara disisi perusahaan mereka membayar karyawan agar para karyawan bisa menjalankan pekerjaan sesuai dengan keinginan dan harapan perusahaan dengan tujuan utama mampu memajukan jalannya usaha perusahaan (Tryanto, 2017).

Lingkungan sosial ekonomi lingkungan dapat mendukung keberhasilan implementasi kebijakan, sejauh mana kelompok-kelompok kepentingan memberikan dukungan bagi implementasi kebijakan, karakteristik para partisipan, yakni mendukung atau menolak, bagaimana sifat opini publik yang ada di lingkungan dan apakah elite publik mendukung implementasi kebijakan. Berdasarkan hasil wawancara terdapat beberapa kendala yang dialami Gasurkes antara lain, kurangnya dukungan dari kasi kesos kelurahan tembalang, masih ada penolakan dari warga seperti pada perumahan elit walaupun Gasurkes sudah melakukan koordinasi dengan pihak kelurahan namun kelurahan juga belum bisa mengupayakan untuk pemantauan jentik di wilayah tersebut. Belum adanya kesadaran masyarakat mengenai kebersihan lingkungan sehingga masih terus ditemukan positif jentik hingga 5 kali, tindakan intervensi seperti pengadaan ikan serta kebutuhan pendukung penyuluhan seperti fotocopy materi penyuluhan dan doorprize untuk penyuluhan di sekolah, dana masih menggunakan gaji pribadi Gasurkes, serta belum dilakukannya upaya pendekatan kepada tokoh agama tidak hanya ustadz melainkan tokoh agama lain seperti pendeta, tokoh agama Hindu maupun Budha serta tempat ibadah seperti klenteng. Jika para pegawai mempersepsikan bahwa organisasi tidak mendukung mereka, maka hal ini akan mengembangkan perilaku sikap negatif di lingkungan kerja. Pegawai mudah stress, kinerjanya rendah dan kepuasan kerjanya juga rendah. Oleh karena itu persepsi dukungan organisasi yang positif menjadi hal yang penting untuk mendorong kinerja baik dari setiap pegawai. Berdasarkan penelitian Rezeki (2014) sebagian besar bidan puskesmas mempunyai persepsi baik terhadap rasa aman terhadap pekerjaan, banyak responden yang merasakan ketenangan dan kenyamanan menyelesaikan setiap pekerjaan namun tidak memperlihatkan hubungan yang signifikan antara rasa aman terhadap pekerjaan dengan kinerja bidan puskesmas dalam pelayanan kesehatan ibu.

Dalam kepemimpinan terdapat pelaksanaan dan pembimbingan, pengawasan dan evaluasi. Fungsi pelaksanaan lebih menekankan bagaimana pimpinan mengarahkan dan menggerakkan semua sumber daya untuk mencapai tujuan yang telah disepakati. Pengarahan oleh Dinas Kesehatan kepada Gasurkes dilaksanakan hanya sekali saat awal penerimaan Gasurkes. Pengarahan berlangsung selama 2 hari yang diikuti oleh seluruh Gasurkes. Akan tetapi pada penerimaan Gasurkes tahap selanjutnya tidak diberikan pengarahan oleh Dinas Kesehatan namun lebih condong kearah motivasi kerja yang berlangsung selama beberapa jam saja. Melalui pengawasan, standar keberhasilan program yang telah dibuat dalam bentuk target, prosedur kerja dan sebagainya harus selalu dibandingkan dengan hasil yang telah dicapai atau yang mampu dikerjakan oleh staf. Sistem pengawasan kinerja Gasurkes dilakukan oleh koordinator kecamatan setiap satu minggu sekali dan kemudian dinas kesehatan melakukan pengawasan satu minggu sekali dengan koordinator kecamatan. Antara evaluasi dengan pengawasan memiliki kesamaan tujuan yaitu untuk memperbaiki efisiensi dan efektivitas pelaksanaan program dengan memperbaiki fungsi manajemen. Evaluasi dan monitoring puskesmas dilakukan setiap bulan yang diikuti oleh seluruh Gasurkes kelurahan dan korcam yang dihadiri kepala puskesmas ataupun pemegang program P2P. Dalam 1 bulan sekali juga dilakukan monitoring dan evaluasi DKK dengan seluruh korcam. Untuk evaluasi dan monitoring tingkat kecamatan dilakukan 3 bulan sekali. Hal ini menunjukkan pengawasan yang dilakukan oleh atasan dalam sebuah organisasi mempunyai pengaruh besar dalam peningkatan kedisiplinan terhadap 
bawahannya. Dengan demikian dalam rangka usaha mencapai tujuan suatu organisasi secara efektif dan efisien pimpinan harus melakukan pengawasan yang baik serta mampu memberikan arahan kepada bawahan untuk selalu bekerja sesuai pengetahuan dan keterampilan yang dimilikinya. Hasil analisis Handayani (2012) bahwa ada hubungan antara kepemimpinan dengan kinerja petugas MTBS dimana semakin baik kepemimpinan semakin baik pula kinerja petugas MTBS. Dukungan dari pimpinan sangat dibutuhkan antara lain memberikan perhatian pada kelengkapan sarana, evaluasi rutin, dan memberi penghargaan atas prestasi petugas.

Berdasarkan hasil wawancara, Gasurkes Kelurahan Meteseh merasa terbebani dengan jumlah target wilayah yang harus mereka lakukan. Dikelurahan Meteseh terdapat 3 orang Gasurkes yang bekerja meliputi $30 \mathrm{RW}$ dengan jarak cakupan wilayah yang terhitung luas serta dengan medan yang naik turun. Hal tersebut dikuatkan dengan jawaban informan triangulasi bahwa mereka merasa kasihan dengan beban kerja Gasurkes Kelurahan Meteseh. Dengan melihat jumlah kasus yang tinggi di Kecamatan Tembalang juga membuat Gasurkes merasa terbebani. Pimpinan dari kecamatan dan kelurahan sering memberi tekanan kepada Gasurkes mengapa kasus DBD di Kecamatan Tembalang selalu tinggi. Menurut hasil penelitian Haryanti (2011) menunjukkan bahwa ada hubungan antara beban kerja dengan keterlambatan pelaksanaan penyidikan epidemiologi DBD. Hal tersebut juga sejalan dengan teori Everly Girdano dalam Haryanti (2011) menyatakan bahwa beban kerja adalah dimana pekerja dihadapkan pada tugas yang harus diselesaikan pada waktu tertentu.

Kegiatan penyediaan tenaga kerja merupakan tahap yang sangat menentukan dalam kehidupan organisasi, terutama jika terdapat tenaga kerja yang mempunyai sifat kepribadian dan mempunyai kemampuan atau keterampilan kerja yang kurang menunjang bagi pelaksanaan organisasi. Gasurkes bekerja dibawah Dinas Kesehatan Kota dan di tempatkan di setiap kelurahan. Jumlah
Gasurkes yang ditempatkan pada setiap kelurahan ditentukan berdasarkan kepadatan penduduk serta luas wilayah kerja. Luas wilayah Kelurahan Tembalang adalah 268,23 Ha dengan jumlah 8 RW 35 RT, dan luas wilayah Kelurahan Meteseh adalah 499,00 dengan jumlah 30 RW dan 186 RT. Sedangkan luas wilayah Sendangmulyo adalah $461,00 \mathrm{Ha}$ dengan jumlah $31 \mathrm{RW}$ dan terdapat 5 orang Gasurkes. Berdasarkan informasi dari informan triangulasi perbedaan jumlah Gasurkes disesuaikan dengan jumlah kasus yang ditemukan pada wilayah tersebut. Berdasarkan penelitian Haryanti (2011) menyatakan bahwa tidak ada hubungan antara ketersediaan tenaga dengan keterlambatan pelaksanaan PE DBD. Namun berbeda hal nya dengan penelitian Yunardi (2008) dalam Haryanti (2011) mengatakan bahwa terdapat hubungan antara ketersediaan tenaga kesehatan dengan kunjungan balita di Posyandu Merpai III. Dalam penelitian Herdywati (2017) menyatakan bahwa jumlah sumber daya pegawai yang melaksanakan tugas dapat mempengaruhi kinerja.

Alat atau sarana yaitu sumber daya yang dapat dipergunakan untuk membantu menyelesaikan tujuan dengan sukses. Alat atau sarana merupakan faktor penunjang untuk pencapaian tujuan. Untuk mencapai hasil kerja yang baik dibutuhkan sarana yang mendukung dan sesuai dengan tugas dan fungsi yang dilaksanakan. Sarana yang digunakan dalam mendukung kinerja Gasurkes berasal dari Dinas Kesehatan Kota. Sarana tersebut berupa senter, materi penyuluhan tentang DBD, seragam lapangan, tas, topi, laptop dan printer untuk masing-masing kecamatan 1 buah, serta form laporan. Berdasarkan penelitian Handayani (2012) menyatakan bahwa ada hubungan signifikan antara fasilitas dengan kinerja petugas MTBS, semakin baik fasilitas semakin baik pula kinerja petugas. Berdasarkan penelitian Kusmiyati (2013) ada hubungan antara sarana prasarana kinerja petugas dalam pelayanan imunisasi campak di Kota Bitung. Ketersediaan sarana prasarana baik fasilitas, alat, dan bahan dalam tugas pelayanan berpengaruh terhadap 
kinerja individu, karena memiliki fungsi membangkitkan motivasi bekerja, mengaktifkan respon pegawai, dan dapat menarik perhatian pegawai. Sedangkan dalam penelitian Husein (2012) menunjukkan bahwa tidak ada hubungan yang bermakna antara saran kinerja petugas. Penelitian tersebut menunjukkan bahwa tidak ada beda proporsi petugas yang menilai sarana lengkap dalam memiliki kinerja baik, karena walaupun terdapat petugas yang menyatakan sarana tidak lengkap namun ketidaklengkapan tidak menjadi kendala berarti bagi petugas sehingga petugas tersebut tetap dapat melakukan penemuan kasus TB walaupun dengan keterbatasan sarana.

\section{PENUTUP}

Berdasarkan hasil penelitian dan pembahasan dapat disimpulkan bahwa kinerja petugas surveilans kesehatan (Gasurkes) Kelurahan Meteseh dan Kelurahan Tembalang sudah mencapai target kerja. Pengetahuan petugas surveilans kesehatan (Gasurkes) di Kelurahan Meteseh dan Kelurahan Tembalang kurang baik. Terdapat persamaan persepsi baik antara informan utama dan informan triangulasi. Kurangnya motivasi dalam memberikan dukungan untuk memaksimalkan kinerja Gasurkes yaitu dari pihak kelurahan. Imbalan yang diterima oleh Gasurkes sudah sesuai dengan ketentuan Perda yang mengatur, Punishment sudah diberlakukan sesuai Perda No 5 Tahun 2010 tetapi belum ada reward atau kompensasi yang diberlakukan tidak sesuai dengan Perda yang mengatur. Dukungan Lingkungan Sosial Ekonomi Politik yang belum optimal serta ditemukan beberapa kendala dalam pelaksanaan. Kepemimpinan yang belum optimal dimana pengarahan hanya dilakukan pada Gasurkes lama. Beban kerja belum merata. Kecukupan tenaga untuk Kelurahan Tembalang sudah mencukupi akan tetapi untuk Kelurahan Meteseh kurang mencukupi. Kecukupan Sarana untuk mencukung pelaksanaan upaya penanggulangan DBD sudah mencukupi.

Saran kepada peneliti selanjutnya diharapkan dapat meneliti faktor-faktor kinerja yang lain bukan hanya dari pengetahuan, persepsi, motivasi, imbalan, lingkungan sosial ekonomi politik, kepemimpinan, beban kerja, ketersediaan tenaga dan sarana. Serta melakukan penelitian yang lebih mendalam agar data yang diperoleh lebih kompleks.

\section{DAFTAR PUSTAKA}

Armaya, P. 2016. Analisis Kinerja Tenaga Surveilans Kesehatan (Gasurkes) Program Kesehatan Ibu dan Anak di Kota Semarang. Jurnal Kesehatan Masyarakat. 4(4):112-121

Dinkes Kota Semarang. 2015. Profil Kesehatan Kota Semarang 2015. Semarang: DKK Semarang.

Handayani, T. 2012. Faktor-faktor Yang Berhubungan Dengan Kinerja Petugas MTBS (Manajemen Terpadu Balita Sakit) di Puskesmas Kabupaten Kulon Progo. Skripsi. Universitas Indonesia

Haryanti, E. 2011. Faktor-Faktor yang Berhubungan dengan Keterlambatan Petugas dalam Melaksanakan Penyelidikan Epidemiologi Demam Berdarah Dengue (DBD) Puskesmas di Kota Semarang Tahun 2010. Skripsi:Universitas Negeri Semarang

Herdywati, A. E., Cahyo, K., Kusumawati, A. 2017. Identifikasi Faktor Penghambat Pencapaian Kinerja Petugas Surveilans Kesehatan (Gasurkes) dalam Upaya Pengendalian Kejadian Demam Berdarah Dengue (DBD) di Kecamatan Tembalang Tahun 2016. Jurnal Kesehatan Masyarakat. 5(3):449-456

Husaini., Awalia, R., Marlinae, L. 2016. Analisis Pengaruh Faktor Lingkungan dan Motivasi terhadap Kepuasan Kerja di Pelayanan Kesehatan RSUD Banjarbaru. Buletin Penelitian Kesehatan. 44(3): 165-172

Husein, R. D., Sormin, T. 2012. Faktor-Faktor yang Berhubungan dengan Kinerja Petugas Program TB Paru terhadap Penemuan Kasus Baru di Kabupaten Lampung Selatan. Jurnal Keperawatan. VIII (1): 52-59

Kusmiyati., Kartasurya, M. I., Wulan, L.R.K. 2013. Faktor Individu, Organisasi dan Psikologis yang Berhubungan dengan Kinerja Petugas dalam Pelayanan Imunisasi Campak di Puskesmas Kota Bitung. Jurnal Ilmiah Bidan. 1 (1): 22-31

Mandagi, F. M., Umboh, J. M. L., Rattu, J. A. M. 2015. Analisis Faktor-Faktor yang Berhubungan dengan Kinerja Perawat dalam Menerapkan Asuhan Keperawatan di Rumah 
Nurina S., Bambang B. R. / Kinerja Petugas Surveilans / HIGEIA 2 (2) (2018)

Sakit Umum Bethesda GMIM Tomohon. Jurnal e-Biomedik. 3(3):884-894

Mardiono, S., Primitasari, A. 2016. Faktor-Faktor yang Mempengaruhi Kinerja Perawat dalam Pelayanan Keperawatan di Rumah Sakit Muhammadiyah Palembang Tahun 2015. Jurnal Kesehatan Bina Husada. 11(4):1-5

Rahmah, N., Lasmini, P. S., Rahmatini. 2015. Hubungan Karakteristik dan Tingkat Pengetahuan Petugas Imunisasi terhadap Praktik Penyimpanan dan Transportasi Vaksin Imunisasi di Tingkat Puskesmas Kota Padang Tahun 2014. Jurnal Kesehatan Andalas. 4(3): 917-924

Rahmawati, F. 2016. Analisis Pengendalian Penyakit DBD Sesuai Peraturan Daerah Kota Semarang Nomor 5 Tahun 2010 Tentang Pengendalian Penyakit Demam Berdarah Dengue di Kecamatan Tembalang. Jurnal Kesehatan Masyarakat. 4 (2): 10-19
Rundungan, R. O., Rattu, A. J. M., Mariaty, N. W. 2015. Analisis kinerja Petugas Kesehatan Gigi Terhadap Pelayanan Kesehatan Gigi dan Mulut di Poliklinik Gigi RSUD Datoe Binangkang Kebumen Bolaang Mongondow. JIKMU. 5 (2a): 414

Rezeki, S. P., Ayuningtyas, D. 2014. Kualitas Lingkungan Kerja dan Kinerja Bidan Puskesmas dalam Pelayanan Kesehatan Ibu. Jurnal Kesehatan Masyarakat. 8 (6): 265-271

Salam, J., Ikhtiar, M., Nurhayani. 2013. Hubungan Gaya Kepemimpinan Terhadap Kinerja Tenaga Kesehatan di Puskesmas Wara Selatan Kota Palopo. Jurnal AKK. 2(2):29-34

Tryanto, D. A. dan Indrawati, F. 2017. Analisis Kinerja Petugas Pelayanan Rawat Jalan Puskesmas Ngesrep Dengan Metode Balanced Scorecard. HIGEIA. 1(2): 1-10 